BOOK REVIEW:

DISCOURSE, IDENTITY AND THE QUESTION OF TURKISH

ACCESSION TO THE EU: Through the Looking Glass

CATHERINE MACMILLAN

Surrey, Ashgate, 2013

Language: English

200 pages

ISBN: 978-1-4094-5560-8 (ebook)

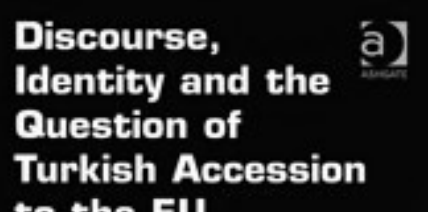

to the EU

Through the Looling Glass

The issue of Turkish accession to the EU is one of the unprecedented cases in the enlargement history of the Union. Although Turkey-EU relations date back to 1959 when Turkey applied for having an association agreement with the EU, the country is still waiting for accession. In view of this prolonged relationship which still could not result in accession, MacMillan aptly argues that Turkey's EU accession is not just dependent on the fulfilment of the Copenhagen criteria but also on the perceptions of EU elites, national leaders of the Member States, and European public opinion, in general.

In this context, Discourse, Identity and the Question of Turkish Accession to the EU: Through the Looking Glass by Catherine MacMillan offers a comprehensive analytical framework that helps European studies scholars grasp the identity dimension of Turkey-EU relations. MacMillan argues that the issue of Turkish accession has led to the emergence of an 'identity crisis' in the EU itself, and, that it has stimulated discussions among EU elites with respect to the construction of an 'ideal identity' for the EU.

The book consists of five chapters, excluding Introduction and Conclusion parts. The study is mainly based on a constructivist approach, which assumes that identities are socially constructed against an Other, especially on the basis of elite discourse. MacMillan innovatively constructs six forms of Othering by making a combination of Diez, Manners and Zarakol's forms of Othering. This theoretical 
framework of the study is drawn in Chapter 1. In Chapter 2, in order to shed further light on the current debates on Turkey's accession to the EU, MacMillan presents how Europeans construct various images of 'the Turk' from a historical perspective. Although the main aim of the book is to provide an analysis of elite discourse, MacMillan argues that elite discourse might be influenced by public opinion to a certain extent. Thus, Chapter 3 provides a discussion of current attitudes towards Turkey's membership in the context of public discussions in the EU. The following two chapters focus on elite discourse with special emphasis on Turkey's accession to the EU. Through an application of Habermas' theory of communicative action, MacMillan examines the pro and con arguments of the political elites regarding enlargement in Chapter 4. Through such analysis, she aims to understand how the political elites conceive the EU because their perceptions are directly related to future enlargements. In Chapter 5, MacMillan scrutinizes different national discourses regarding Turkey's membership by using Foreign Policy Discourse Analysis (FPDA). For this purpose, Britain, France and Turkey itself are chosen as the case study.

The overall analysis of MacMillan offers two significant findings. Her first finding is that there is a basic division among the EU elites: There are those who support Turkey's accession in principle and those who reject it on the basis of cultural, religious, and fundamentally non-European terms. Indeed, this division results from how the EU perceives itself. MacMillan concludes that supporters of Turkish membership perceive the EU as a rights-based, post-national union based on universal values, such as democracy, and, a problem-solving entity based on benefits, particularly in the field of security and economy. Thus, Turkey's accession is valuable for the EU. Rejecters emphasize the EU's cultural identity, with its roots in the religious and cultural heritage of Europe, which they regard as very different from those of Turkey. Her second finding is that there is a parallelism between national discourses on a state/nation and the EU, which has a strong impact on debates about Turkey's membership. As an example, the French case shows the strong identification of the French state with Europe, so the EU is accepted as a political actor having a strong identity and clear borders. In that case, enlargement, particularly in the case of Turkey's membership, is seen as a factor weakening European integration.

The major contribution of MacMillan's book is that it successfully categorizes historical aspects of the European opposition to Turkey's membership on the grounds of identity claims. By doing such an analysis, MacMillan reveals that European opposition towards Turkey's membership is not only limited to current identity debates. On the other hand, MacMillan also uses identity claims in Europe to support Turkey's accession. By stating different views of Europe (a value-based community vs. a rights-based post-national union), she aims to help readers grasp 
how such different views of Europe have significant effects on debates over Turkey's membership as well as European debates over the EU's enlargement in general. In addition, while doing that, she also compares the debates over Turkey with those over the Eastern enlargement.

Regarding the methodology of the book, firstly, it can be said that MacMillan presents a well-organized literature review in the second chapter when she analyzes the historical Othering of Turkey. Secondly, in the last chapter, using FPDA marks the book's difference from others which cover identity issues in Turkey-EU relations from a constructivist perspective. In that sense, the use of FPDA is a useful analytical tool. However, there are some weaknesses regarding its application. The main weakness is that the time frame of the examination is not stated clearly. She might have stated a specific time frame, such as between December 1999 Helsinki European Council when Turkey was granted candidacy status and the end of 2012 (a date close to the publication of the book). It might have made the analysis easier to read and follow. The second weakness is related to her collection of data. MacMillan uses the primary sources including "parliamentary debates, speeches by ministers and party manifestoes and position papers" (p. 113-114) when she analyzes discourses. However, for such a methodologically rich book, she could have supported her study with in-depth qualitative interviews to make her study more credible.

Apart from the methodology, the fundamental weakness is that MacMillan mentions the relationship between public opinion and elite discourse; however, it is not sufficiently problematized and analyzed in her study. It seems disconnected to the overall scope of the book. She might constitute and develop this connection in the future edition of the book or in her other studies.

All in all, MacMillan's book seems as a fine contribution to the literature on the constructions of Turkish and European identities. Despite some methodological weaknesses, MacMillan offers a comprehensive analysis. Therefore, this book can be recommended to students and researchers of European studies, especially to those who try to understand the ups and downs of the Turkey-EU relations from identity and discourse perspectives.

\section{EBRU DALĞAKIRAN*}

\footnotetext{
* Research Assistant, Marmara University, European Union Institute, Department of EU Politics and International Relations, e-mail: ebru.dalgakiran@marmara.edu.tr
} 